\title{
Sufism Practices at Ma'iyahan Emha Ainun Nadjib
}

\author{
A Faiz Yunus ${ }^{1} \&$ Muhammad Luthfi, ${ }^{2}$ \\ $\left\{\right.$ 1 jabriexfaiz@gmail.com, ${ }^{2}$ m.luthfiz009@gmail.com $\}$ \\ ${ }^{1,2}$ School of Strategic and Global Studies, Universitas Indonesia, Indonesia
}

\begin{abstract}
This research is more focused on Jamaah Ma'iyahan Emha Ainun Nadjib reviewed through Sufism approach. So to review further whether Ma'iyahan is a tarekat as in Sufism?, how the practice of Sufism performed Emha Ainun Nadjib in Ma'iyahan?, what are the values of Sufism contained in Ma'iyahan? Researchers studied the method of acculturation of Sufism conducted by Emha Ainun Nadjib in "Ma'iyahan" through a descriptive analytical approach. Descriptive method is a method in researching the status of human groups, conditions, systems of thought, or phenomena at this time. With the view to making a systematic, factual and accurate description of the facts, traits and relationships among the phenomena under investigation. (Mohammad Nazir, Sample Research Method: 1988: 63). Researchers will also study through discourse analysis approach as one of the methods that can help this research get approach to the object in carefully, such as through the text approach that is Emha Ainun Nadjib writings relating to Ma'iyahan, interview as validation to the text found.
\end{abstract}

Keywords: Emha Ainun Nadjib, Sufism, Maiyah, Social, Culture

\section{INTRODUCTION}

Allah as the Creator of the universe and all life forms in it with Qudrah and His Iradah. Then return it (creation) to its origin (doomsday). All that as a creature that is temporary in the life of this universe.

Man as God's most perfect creature becomes the main character in this life drama. The beginning of the creation of the universe derived from the creation of Nur Muhammad is the starting point of Allah creating the Universe and all. The man named Adam became the early form of Nur Muhammad as the man who served as the Caliph on earth.

Civilization became the beginning of world life. Human beings as intelligent creatures as differentiators of His other creatures. Without civilization the rotation of life on earth will never run as it should. Civilization as the initial implementation of the formation of a culture created by humans with his mind so that he (human) is recognized its existence. As a rational creature necessarily need a partner in living it. Culture is also a tool that is used as a social contract between humans with one another with other creatures (human) and of course as a form of servanthood to his God (Allah). 
Religion is the logical consequence of the creation of humanity and the civilization it carries that gives rise to culture. With the formation of civilization and culture, then it becomes something that must be lived by humans as a guide in living this life. In religion must have the standard literature as a guide to live it. Zabur, the Torah, the Gospel and the Qur'an are laws established by God as guides in religion, civilization, culture and living.

Islam is the last religion revealed to man as the perfect of previous religions and al-quran as the perfecting of the previous guidebooks. Muhammad SAW becomes the ultimate messenger who carries God's messages to humans and all beings in the universe for the continuity of life's rotation. In the book Social Tasawuf which is deaf by Prof. Dr. H. M. Amin Gratitude, MA, that Islam as a force of ethics and action of development, is essentially a religion with a professorial character. Namely as a religion that is revealed to radically change the oppressive socio -cultural order, a system that restricts, overrides the perpetrators and the system that is not clear the direction of history. Thus, Islam is present as a religion that puts social charity as the mother or central to the meaning of human existence.

Along with the development of the times, especially in the last quarter of civilization, Islam began to influence, shape and polarize (institution) against the groups of bathiniyah and dhahiriyah that exist in the system in society.

The emergence of movements inspired by the influence of Islamic values brings Islam to the region or to hard and soft content. This is because of the socio- political influence and the circumstances surrounding communities. Especially in the last 21 century Islamic movements are very clear influence on social and political life of the world. Actually, in Islam itself is not as rigid as understood by a radical group whose orientation leads to violence. Islam, however, positions itself as a blessing to all nature, meaning there is no compulsion in Islam to make certain groups (religions) or local values a value brought by Islam.

Islam as a teaching system must be understood and applied in the modern world as a doctrine that carries the value of independence, intact, moderate that can be a partner of local value. That is why many models of Islamic movements with their respective content are inspired from the values brought by Islam that awaken the Sufi commonly called the tarekat. Like the phenomenon that occurred in Indonesia. The emergence of extremist groups makes Islamic insights rigid in Indonesia, but this gives new zeal to other groups who have a nonextreme Islamic understanding. So, in this study researchers will be examine the Islamic movement that emerged and developed in modern times. In this case the object to be studied is movement brought by Emha Ainun Nadjib with frame 'Maiyah' As a group or movement that became the polemic damper of religion and nationality that occurred in Indonesia especially in the field of Sufism.

Researchers assume that Ma'iyahan is one of the models of tasawuf practice in Islam that is adapted to the needs of the present time. So, it is interesting to be the object of the researcher with the title "Sufism Practices at Ma'iyahan Emha Ainun Nadjib."

\section{METHOD}

\subsection{Research methods}

This study uses descriptive approach and discourse analysis, is a systematic, factual and accurate description of the facts, properties and relationships between the phenomena being investigated. Technique of data collecting is to study primary data source which come from printed and electronic book about tasawuf and its practice especially Ma'iyah by Emha Ainun Nadjib and secondary sources come from book, journal, thesis, and interview and article in internet. 
To achieve the purpose of this study research method that researchers use is a qualitative research method, the method more dependent on lingusitik data than numerical data and using the base meaning in data analysis (Robert Elliot, Ladislav Timulak, 2013: 147). Besides, the approach that the researcher chooses is a qualitative descriptive analysis approach, where the purpose of descriptive qualitative research is to produce a comprehensive conclusion about the specific events experienced by individuals and groups (Vickie A. Lambert, Clinton E. Lambert, 2014: 2).

Descriptive research serves to describe, explain and interpret contemporary conditions, this study focuses on conditions, practices, structures and differences or relationships that exist, opinions and processes that are ongoing or a trend at a certain time. While descriptive analysis research not only stops on the description and explanation of the condition alone, but also involves the process of identification and interpretation of the data that has been described previously.

\subsection{Theoretical Framework}

Hearing the word Sufism is of course we will wonder and think tasawuf is a religious understanding that rejects all forms of earthlyness. Basically, the misunderstanding of the public towards tasawuf as a 'conservative' understanding makes the common people rasist and afraid to learn tasawuf. Though the views and understanding is not true.

Basically, Sufism is a branch of scholarship in Islam which is the result of a combination of culture after Rasulullah SAW. Died. The term tasawuf itself at the time of the Prophet was still not there, there is only a friend name, then after the friend of the generation of the Muslims tabi'in.

Shaykh Abu Nasr as-Sarraj explains the notion and essence of Sufism in his book AlLuma', that Sufism is a noble character that appears in glorious times with the noble people as well (As-Sarraj, 2002: 53). While the perpetrators are secured shufi, the chosen people of God from his creatures who know the laws of God, practice and realize what is taught and commanded by God and live what he has realized (As-Sarraj, 2002: 57).

Etymologically, Sufism comes from Arabic, Tashawwafa, yatashawwafu, Tashawwufan. In this case different scholars explain it. Some say the word shuf (fleece), shaf (line), shafa (clear) of the word shufah (the terrace of Masjid Nabawi occupied by sebgaian companions of the Prophet SAW.) (Gratitude, 2004: 3 -4). Differences understanding and explanation of the origin and meaning of Sufism is motivated by the spiritual experience and phenomena that exist in the Sufi itself.

Sufism is one of the phenomena in Islam that focuses on cleansing the spiritual aspect of man. Among the spiritual being in man is the spirit. Imam al - Ghazali in ihya 'ulumuddin gives an understanding of the spirit that is as something derived from the inner spaces of the human self, which revives the functions of human jasadiyah which subsequently generate noble morals (akhlaq) (Al-Ghazali,

1987: 17). Through this mysticism (tasawuf) one can know how to set the soul, heart and use the feelings, thoughts, and all the enchantment of a salik (the ones who are on the way to God) a secret journey to the secret place (Sirr) (Al-Jailani, 2017: 122-123)

to remain istiqomah (consistent) in his devotion to God (Ni'am, 2011: 70).

In the book of Sirr al-Asrar, Shaykh Abdul Qadir al-Jailani mengurainkan the term tasawuf consists of four letters (فت و صت) namely, Ta' (ت), Shad (ص), Waw (و), Fa' (ف). Each of the letters has its own meaning, Ta' (ت) means Taubah, as the first step in the journey to God. The next is the letter Shad (ص) which means that Shafa as the second level is a state of peace with 
free from unrest and distress by approaching God through dhikrullah (remembrance of Allah) as a cleansing effort to go to the secret center (Sirr). The third letter is Waw (و) which means Territory (waliyullah), that is the holy and silent state that exists in the souls of the lovers of Allah and Waliyullah. The last is the Fa' (ف) symbol representing mortal', the abolition and emptying of all shapes and forms (Al-Jailani, 2017: 124-128). Allah said in the surah alQashash, 88:

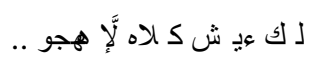

Meaning: "Everything must perish, except Allah ..." (QS. Al-Qashash: 88)

The review of Sufism shows that the Sufis with their various schools have a conception of the path (tariqat) to God. This path begins with spiritual exercises (riyadah), then gradually takes various phases, known as level (maqam) and state (Al- hal), and ends by knowing (ma'rifat) to God. The level of recognition (ma'rifat) characterizes a salik (Sufism Activist) in reaching the highest level in the concept of tasawuf (Yusuf, 2003: 200). KH. Ihsan, Jampes, explains in his book Siraj al- Thalibin, (Dahlan, 1930: 70):

"Compliance is mandatory for the seekers of the afterlife to collect between the Shari'a, the tarekat, and the essence and should not dispose of either of them. The reason, because the essence without the shari'a is kebatilan and shari'a without reality is empty"

This means that the understanding of Sufism must begin with the understanding of syari'at as the initial foundation to equip themselves to study tasawuf. But that does not mean then leave the sharia itself. For the framework of the attitude and behavior of the Sufis is manifested by certain deeds and methods in the form of tariqat, or the way to discover the recognition (ma'rifat) of God. The scope of the journey towards Allah to obtain recognition (ma'rifat) which prevails among Sufis is often referred to as an 'Irfani framework.

Prof. Dr. H.M. Amin Gratitude, MA explained in his book entitled Contextual Sufism: The Solution of Modern Human Problems, that Sufism is a field of Islamic science with various divisions in it, namely tasawuf akhlaqi, tasawuf amali, and tasawuf falsafi. Tasawuf akhlaqi in the form of moral teachings/morals in which includes the teachings of takhalli, namely the purification of the properties of reproach, takhalli, which adorns and refrains with praised deeds, and tajalli, namely the disclosure of the Nur Ilahiyah (Light of God) along with the loss of the characteristics of arrogance On the human self. While the tasawuf amali is a guide how to get closer to God, this is identical with the tarekat. Philosophical Sufism, is a philosophically profound study with all aspects of it integrated between the intuitive of Sufism and the rational vision of philosophy (Gratitude, 2014: 1-4).

Based on the description of Prof. Dr. Amin Gratitude is, that tasawuf is morality including akhlaq to Allah which aims to form human character having good attitude and mental attitude, moral man, good to self, others, environment and God.

While the Movement (social movement) is a common challenge that is aimed at mutual goals and solidarity, in continuous interaction with elite, rival or enemy, and authority (Wiktorowics, 2012: 11-16). Social movements that exist in society certainly can not be separated from the spiritual value as a belief in the Creator. In the book of the Spiritual Aspect in Nursing (Hamid, 2000: 26), written by Achir Yani Hamid argues that spirituality includes the following aspects:

1 deals with something unknown or uncertainty in life, 
2 how to find a meaning and purpose of life,

3 have the ability to realize inner strength to use the inner resources and strengths,

4 have a feeling of being tied to yourself and with the Creator.

Spiritual can also be defined as an integrated aspect of humanity as a whole characterized by meaning and hope. Spiritual health or well-being is a sense of harmony between each other, with nature, and with the highest life. This sense of harmony is achieved when one finds a balance between individual values, goals and belief systems with their relationships within themselves and with others. This belief is often rooted in the person's spirituality. Throughout life an individual may be more spiritually grown so that the individual becomes more aware of the meaning, purpose and value of life.

Religious social movement is also a very effective means of propagation using tasawuf method that is through acculturation of Sufism itself. As expressed by Drs. A. Busyairi Harist, M. AG (Harist, 2012: 113-117), that da'wah can not be separated from the vast socio-cultural component:

1. Input, which includes:

- Raw-Input, which combines the teachings of Islam as a whole with the formulation of the results of understanding of Islam from various aspects.

- Instrumental-input, ie methods, facilities, facilities, and funds da'wah.

- Environmental-input, that is, the problematic of da'wah and all socio- cultural problematics in a broad sense.

2. Conversion, the creativity of a da'i to his mad'u with the ability to collaborate on input and output in all da'wah activities.

3. Out-put, namely the realization of a community of believers (iman) and cautious (taqwa)

4. Social environment that has a lot of influence on da'wah system and method

5. Feedback, which serves to give positive and negative influence on da'wah system.

Sufism presents itself to the public with a movement known as the tarekat. Ie the tarekat as an application of the teachings of Sufism as a method or system. According to the term tasawuf, the tarekat is a journey of a salik (tarekat) toward God by purifying himself. As Abu Bakr of Aceh gave the tarekat's definition in the book of Wasiat Tarekat Hadratus Sheikh Hasyim As'ary (Ni'am, 2011: 84), that:

"The way, the guidance in performing a worship in accordance with the teachings specified and exemplified by the prophet and done by friends and tabi'in, from generation to generation to the teachers, connect and chain together; Or a way of teaching or educating, gradually expands into a kinship that binds like-minded Sufi adherents to facilitate the receiving of the teachings and exercises of the leader in one fellowship."

Therefore, Islam as a universal religion has values for the formation of self and human development into human beings based on Al-Qur'an and Al-Hadist as the basic guidelines and asasses in religion and in the community. 


\section{RESULT AND DISCUSSION}

\subsection{A Glance of Biography of Emha Ainun Nadjib and His Ma'iyah}

Emha Ainun Nadjib or Cak Nun was born in Jombang, East Java on Wednesday, May 27, 1953. He studied at Pondok Pesantren Gontor, and "stopover" at the Faculty of Economics, Gadjah Mada University. Emha is both a scholar and a humanist, skilled in initiating and singing words. His writings, both his essays, columns, short stories, and his poems adorn many leading print media (Nadjib, 2016:

273-274). Emha is also the driving force behind the Kiai Kanjeng music group and the Jamaah Ma'iyah commemoration community that is scattered in various cities in Indonesia (Nadjib, 2016: 345).

As a social worker Emha Ainun Nadjib or cak Nun there are at least five monthly events held in several regions in Indonesia, namely (Nadjib, 2016: 218): Padhang Bulan (in Jombang), Macopat Syafaat (in Yogyakarta), Kenduri Cinta (in Jakarta), Gambang Syafa'at (in Semarang), Obor Ilahi (in Malang), Bangbang Wetan (in Surabaya). Beyond these five events Emha also serves invitations from various quarters to contribute enlightenment and search for solutions to common problems. Another routine that Emha does is to name the newborn baby her parents ask (Nadjib,

2016: 245-246).

In these social gatherings he undertakes various deconstructs of understanding of values, patterns of communication, the education of ways of thinking, and the pursuit of solutions to societal problems. Ma'iyah who in the care of Emha Ainun Nadjib is not the slightest change the local customary circumstances that have been applicable in the community. As the naming of ma'iyah with their respective themes in different places, such as in Malang, that the ma'iyah previously existed under the name of the Obor Ilahi but dimmed, the previous initiator's character collaborated with Cak Nun and Kiai Kanjeng without changing the name. In the words of Ushul Fiqh explained, that:

$$
\text { ةظ فاحملا دـ لع م بدق للا حلا صدلا ذخلأاو دي دجلاب صدلأحل }
$$

"Maintaining good old things and taking on new things better"

Together with Kiai Kanjeng, from the 6th year of its founding (June 1998 to June 2013), Emha has visited more than 22 Provinces, 376 districts, 1,430 sub- districts, and 1,850 villages across the archipelago. Emha is also often invited to various countries, including 6 cities in Egypt, Malaysia, and a series of tours of Europe: England, Germany, Scotland, and Italy. In March 2006 Emha was invited to Malaysia and Brunei Darussalam. In late 2006, Emha and Kiai Kanjeng made a series of trips in Finland and the Amazing Asia and Culture Forums event at the invitation of Union For Chritian Culture. And in June 2013 Emha Ainun Nadjib with Kiai Kanjeng visited several universities in Morocco, including Mohammed V University in Rabat city and $\mathrm{Al}$ Akhawayn University in Ifrane city.

\subsection{Explanation Ma'iyah}

Is Maiyahan a tarekat as in Sufism or just a method of da'wah? The tarekat is derived from the Arabic, Thariqah, which means al-Khath fi al syai (line something), al-Shirath and al-Sabil (road). This word also means as al-Hal (state) as it is contained in the phrase "huwa 'ala 
tariqah hasanah wa tariqah sayyi'ah" (being in a good state of road and a bad road). The word tariqah is used in the Qur'an which is defined as the way or way used by someone to do something (Gratitude, 2014: 44-47).

It can be understood practically, that tariqah is an esoteric religious practice, performed by a Muslim with certain practices in the form of wirid and dhikr who have transmission or chain from murshid to murshid to the Prophet Muhammad, Even to Gabriel then Allah SWT (Syukur, 2014: 145).

While the da'wah etymologically comes from the word "Da'a-Yad'u- Da'watan", which means calling, inviting, inviting, praying, asking, and calling (Al- Munawwir, 1984: 438-439). Meanwhile, according to the terminologists the experts define it differently, such as Sayyid Qutb gives the meaning of da'wah is "Invite/invite other people into sabilillah not to follow da'i or not to follow a group of people". Quraish Shihab says that da'wah is a call or an invitation to the conviction or attempt to change the situation to a better and perfect situation, both to the person and society (Syamsuddin, 2016: 9-10). With the aim to convey the truth of the teachings that exist in the Qur'an and al-Hadist and invite humans to practice with some elements contained in it, namely, the first, the subject of da'wah as executor da'wah tasks. Second, the object of da'wah as indvidu or a group of people who targeted and became the suggestion of a da'wah activity. Third, propagation material that is content or content as a message to be delivered by da'i to da'wah object as contained in al-Qur'an and al-Sunnah. Fourth, the method of da'wah, the ways used by a preacher to convey the message to the object of da'wah both kepda individual and certain groups of society with different approaches according to local customary circumstances. The last is the foundation of da'wah, which divides into three meanings (Syamsuddin, 2016: 11-16):

1. Da'wah Bil Hikmah (wisdom), is the delivery of da'wah adapted to the circumstances that can be shaped, lecture, give donations orphans, and so forth.

2. Mauidah Hasanah, is to give advice with a bai speech, gentle and courteous without offensive and without any sense of compulsion.

3. Mujadalah (exchange ideas in a good way) to find a solution of every problematika that exist in the community.

When understood in a broader perspective, da'wah is a simultaneous movement in various fields of science and life for the happiness of mankind and introduces Islam in interesting ways. These forms of propagation are constantly being reformed, but not necessarily conforming to the advancements of the times, but standing in accordance with the principles of Islam by modifying their transmission in their culture.

Ma'iyah comes from the Arabic ma'a, which means together, along with Ma'iyyatullaah, togetherness with God. Ma'iyyah is togetherness, Ma'anaa, with us. Ma'iya, with me. In the tradition of sufism ma'iyah means maiyatullah, with God that is the meaning that comes from the circumstances experienced by the Prophet Muhammad and his companions. Abu Bakr was in the cave of the Throne while being pursued by the enemy where Muhammad SAW declared to his companions "Allah is with us" (Alu Shaykh, 2008: 135-136), as narrated in the Qur'an surah at-Taubah: 40

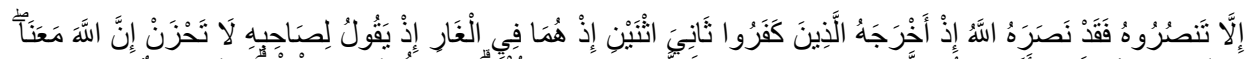

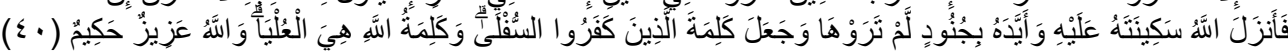

40. If you do not aid the Prophet - Allah has already aided him when those who disbelieved had driven him out [of Makkah] as one of two, when they were in the cave and he said to his companion, "Do not grieve; indeed Allah is with us." And Allah sent down his 
tranquillity upon him and supported him with angels you did not see and made the word of those who disbelieved the lowest, while the word of Allah - that is the highest. And Allah is Exalted in Might and Wise.

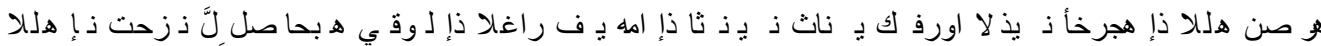

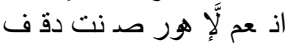

It means: "If you do not aid the Prophet - Allah has already aided him when those who disbelieved had driven him out [of Makkah] as one of two, when they were in the cave and he said to his companion, "Do not grieve; indeed Allah is with us."

Jama'ah Ma'iyah Kenduri Cinta since the 1990s was held in Ismail Marzuki Park. Kenduri Cinta is one of the cultural and humanitarian forums that is packed very open, light and clothed in a cross-gender art title, held in Jakarta once a month.

Based on the information obtained from Emha Ainun Nadjib's assistant, Fahmi Agustian provides an illustration and explanation, that ma'iyah or mai'iyahan is a forum that has been going on for quite some time, with the process and the long journey. Ma'iyah is also referred to as a science laboratory that collaborates all, no distance is so far between an audience with a resource person. In a more specific sense ma'yah can also be called an Educational Institution which is certainly not a very formal institution like most educational institutions today.

If drawn in more detail, the atmosphere of the forum that was attended by thousands of people in these various places, in every jamaah ma'iyah as if it had embedded an awareness to jointly maintain at least 3 forms of security with each other:

1. security of dignity,

2. security of property and

3. security of life.

The discussion forum that lasted only 6-8 hours is not an ideological distraction. In the absence of an authoritarian system, not dependent on one figure strongly reinforces the awakening of the spirit of seeking what is right, not who is right. The truths they take will each test themselves in their own lives.

That in Ma'iyah, there is no term that someone is clever or stupid. Everyone has an awareness that they bring "empty glass" to be filled in Ma'iyah. And most importantly, the Ma'iyah is conditioned to have no guarantee of getting anything from Ma'iyah. Everyone is present for their own consciousness, for their own clarity, on their own initiative. There are no promises that those who come will get something. But precisely with the nuances that are awakened like this, jama'ah ma'iyah are trained to really be able not to put the materials first.

Ma'iyah does not teach that people do not need money, but ma'iyah inculcate the accuracy of thinking so that jama'ah ma'iyah are trained to precisely put something on its proportion (Nadjib, 2015: 19). In the ma'iyah there is also the concept that ma'iyah affirms the position of the fraternal world-the hereafter, they are determined to help each other. For jama'ah ma'iyah they help each other for three reasons.

First, because they are God's servants. Second, because they already believe each other and ensure that they are human. Third, because they are ma'iyah (Nadjib,

2015: 32-33). In Ma'iyahan also always be understood with the values of humanity without limit as long as the value is not deviated from religious values.

As stated by Enha Ainun Nadjib or familiarly called Cak Nun, that what we are doing now is planting and continuing to plant. We never know when our fields will harvest. We never 
know when God allows us to harvest. What we are doing now is to keep the process going on how what we plant to keep awake. When there is a disturbing pest, we clean it together, when there is a rainstorm or a gust of strong wind, we save together. The spirit of ihdina shirotolmustaqiim should still grow in our hearts.

Cak Nun finds a format to frame all his activities and thoughts. The frame was named Ma'iyah, an acronym from Maiyatullah. According to Dr. Nursamad Kamba, Ma'iyah is the work of Sufistic Cak Nun. Dr. Kamba found ma'iyah concept throughout history in only 3 contexts. First, when Rasulullah and Abu Bakr were on

their way to Yathrib and were almost captured by the Meccan Qurays. Secondly, it was introduced by Ibn Arabi. And third, introduced by Shaykh Yusuf al Makassari. As a Sufistic work, Ma'iyah contains akhlaq values possessed by Sufis, but by Cak Nun articulated with modern life. There is no doubt that Cak Nun is a "salik", a spiritual pather with the ability to articulate philosophical thoughts and translate the metaphysical world to the direction of Tawheed. Nothing wrong if Dr. Kamba states that Cak Nun is the "spiritual disciple" of Ibn Arabi (Sabana Magazine 7th edition II, May 2015).

Cak Nun has an alluring communication capability. His voice is good and character. As a person who has been in touch and engaged in theater, he uses his knowledge of stage and acting to support his method of mass communication. Aided by his high sense of humor, Cak Nun became the stage idol. Plus the background as a Poet. His choice of words, the composition of the sentence, is always beautiful and sharp despite being spoken spontaneously.

This distinctive character certainly can not be printed or equaled by anyone. Cak Nun brings Islamic, philosophical, tasawuf, Tawheed and scientific insights to the audience with an easy-to-understand, happy and happy language. That is what Cak Nun has in his social service activities. Supported by Kiai Kanjeng Cak Nun performs social services framed in Ma'iyahan pigora. Although up to now, Ma'iyah is still moving to find the right formula for himself, in his day.

According to Prayogi R. Saputra Ma'iyah is a flexible and articulate terminal that brings and translates Sufism ideas into everyday life. Ma'iyah also not only succeeded in making tasawuf as a worldview and translating its complex ideas into applicable in everyday life. However, while providing contemporary context in various areas of life. Both from a cultural, social, economic, democracy and even in a global politics (Saputra, 2012: 37).

Ma'iyahan who is nurtured by Emha Ainun Nadjib presents a forum that is held once a month in an outdoor place, sitting together once a month for an average of five to seven hours without inviting anyone, no one telling them, or obliging them to come together ( Nadjib, 2015: 17). At 8 pm until 3 am. In ma'iyah the content of Sufism values is very visible from the behavior of the congregation and the material submitted, although the concept of ma'iyah is similar to the tarekat but which distinguishes it is the absence of a murshid as practiced by a person following a particular tarekat. In ma'iyah there is no structure of teachers and students. In it everyone is a disciple, who desires in this matter wanting knowledge. The absence of teacher and student structure in maiyahan is not without foundation, they regard the two words teachers and students make science not achieve harmony of science (Nadjib, 2015: 5). In Ma'iyahan in the stimulus how the pilgrims actively fill the forum with their respective scientific level. The understanding of the ma'iyah in life is like an unbounded circle, where every point of the outer or inner surface of any side of it is infinite. This is like the science and the secret path to the authenticity of life that ma'iyah people call God (Nadjib, 2015: 66). 
This is as contained in the book of al-Hikam by Ibnu Atha'illah As-Sakandari (AsSakandari, 2017: 21), that:

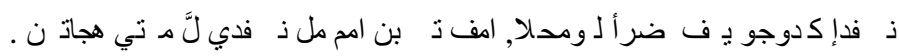

"Bury yourselves in the land of lowliness, for something that grows without being buried (planted) the result is less than perfect."

The point of the phrase is that a person 'does not have to resort to the causes of popularity, such as offering himself for a position that can make a person famous. "If you are forced to be famous, you must be humble and do not seek a certain position". Abu al-Abbas rahimatullah said: "Who wants popularity, he is a slave of popularity. Who loves the ruler, he will become the slave of the ruler? Who worships Allah, for him is the same, famous or not."

\subsection{Content of Sufism Values in Maiyahan Emha Ainun Nadjib}

Muhammad Ainun Nadjib or Emha Ainun Nadjib or Cak Nun as Muslim intellectuals. His Islamic thinking is beyond the mainstream path of the renewed Islamic Thought Reform in Indonesia. Cak Nun's main idea is to accompany the 'Searchers'. Cak Nun plays a major role in unlocking the enlightenment, stalling and expanding the horizons of science and initiating the consciousness of Tawheed to the seekers of God. Could be, this tendency grows from his personal experience with Umbu Landu Paranggi. Thus, the tendency to accompany the Seekers becomes an unconscious ecosystem. This is evidenced by the "Ma'iyahs people" who generally do not accept and accept the generally accepted doctrines of the Islamic way (Nadjib, 2015: 19).

This search anxiety then finds its oasis on Cak Nun's thoughts. Cak Nun's thinking is more responsive to the Searchers than the religious doctrines in general.

This is because the approach in the da'wah Cak Nun which depart from the problem and is personal.

Ma'iyah or Ma'iyahan as a tool for the seeker provides a great opportunity to all those who want and want to be consistent in wading the ocean of scholarship. Which is often delivered by Cak Nun about Tawheed as one of the foundations of Islamic scholarship he explained clearly as if between servant and his God no distance with the lay language Cak Nun explain it. For example Cak Nun always answers questions from the audience with a very simple and weighty reason, following snippets that once researchers follow in Ma'iyahan in Isma'il Marzuki Park in Central Jakarta asked how Islam lives in the era of globalization? Then Cak Nun answered:

"It's up to God" Yes it's not a problem. Wong Islam is a doctrine of values that gives only choices. If you want to come please, not even yo sak karep. Wong is now all complicated. In the mass media we see people squirming, as if nothing wrong in life. When the fasting season everyone wears the hijab, but after that all naked. Newspapers are also so, if fasting busy to make an interview that seems Islamic. But after that it passes."

This is, in contrast to the general doctrine of the ulama' who introduced Tawheed as knowledge, in Ma'iyahan Cak Nun introducing Tawheed as a personal experience. Cak Nun dispensed the search engine on one's consciousness so that he would actively move on his own 
to find what he needed. Cak Nun does not mean negate the intervention of God over man. He is fully God-centric. This approach is a synthesis of the methods of tasawuf and knowledge (Nadjib, 2015: 28).

Sufism introduces Tawheed only as an "unauthorized" personal experience to describe and its circulation is limited only to the teacher's and pupil relation ships that have been cleared (inaugurated) as practiced in the tarekat with the presence of the Murshid, as a way of understanding the science of Sufism Generally guided by a murshid to be more guided in knowing himself and his God. While Tawheed as knowledge is very likely to just stop as knowledge. Cak Nun synthesizes the two in different ways. In Ma'iyahan Cak Nun "unlocks the secrets" of the Sufis in the presence of the public so that everyone can access the wisdom of Sufism without the need to belong to one of the tariqah groups. "There can be no one among the people and their Lord" (Nadjib, 2015: 85). Al-Khawwash in the book Ma'rifatul Ma'rifah, says:

"If al-Haq has appeared (in the heart) then He appears without any visible (badi if badi) and nothing is visible where if nothing is visible. For al-Badi (the Seer of the All-Seen) will obliterate everything that comes to mind from al-Badi 'side, so that no one ever comes across where only He comes. All that happens because of the closeness of a servant with al-Haq" (As-Sarraj, 2002: 716).

This is expressed by Cak Nun with a straightforward language for the al-Khawwas statement in Ma'iyahan:

"I want to say one thing, 'not even a personality in the life of the original man. You do not think that prophet Muhammad is a prophet of muhammad, as long as you still think that muhammad is his son father abdullah and mother aminah, you are mistaken. If you consider me is emha ainun Nadjib it is the source of your suffering in the future, because I am not emha ainun Nadjib ,, yes .."

Emha's statement in Ma'iyahan is in harmony with what is said by Shibli, the Sufi is he who sees nothing in two worlds except God (Al-Hujwiri, 2015: 49).

Through their ma'iyah they long for the absolute thing of God. They put God first on everything else. Being a Sufi does not mean negating the world, but the effort of how the hands keep working, while the heart continues to unite with Him. According to Al Ghazali, true self-knowledge consists of the knowledge of: who you are, where you are from, where and where are you staying here for a while? What are your happiness and your misery? Etc. People who reached the Sufi level may be mediocre, similar to their left-right neighbors, but their minds are radiant with the presence of God (Al-Ghazali 1989: 53).

There are four levels to be a Sufi, the first level is sharia, which contains a moral or ethical basis, and this is found in all religions. In Arabic sharia means "way," the way to true truth. The second level is tariqah. Literally, tariqah means the road to the desert of the Bedouin tribe. Because through the desert, the trail becomes invisible. Tariqah is an inner practice for the soul of the person to be clean and pure. The third level is haqiqah which contains a direct experience of God's presence within. Without this inner understanding, the behavior or doctrine followed is only mechanical in character. While the highest level is a ma'rifah which is more than a momentary spiritual experience. In this level of harmony with God and the truth will continue. 
In the level of sharia the "formula" that applies is: yours and mine. That is the law that guarantees individual rights and ethical relationships between them. At the tariqah level applies the formula: mine is yours and yours is mine. Here there is a strong relationship of friendship. At the level of haqiqah the formula: no mine and no yours. This is the level of realization that humans have nothing because everything is God's. Human beings only carry the mandate, and this goes beyond the attachment of self to worldly, rank, position, fame, wealth. While at the level ma'rifah formula: "no me and no you", because there is only God.

We must believe in the love and power of God, and this ma'iyah is only one purpose for God and His beloved to host our hearts. We are very small and weak to the power of God that we hold firmly in ma'iyah. To be accepted by God is only sincerity, because whatever events in this world do not make us "patheken" (Java language), as long as God is not angry with us. If this is fulfilled, then God will grant victory, compassion and help (Nadjib, 2015:53-56).

Emha or Cak Nun also blessed with charisma to inspire the hearts, enlighten the mind and "subdue lust", as described in the book Sirr al-Asrar Sheikh Abdul Qadir Jilani, that lust should be curbed and controlled so as not to bring man pit, destruction (Al- Jailani, 2017: 79). Takwa as the antidote to the wild appetite. Namely takwa to Allah SWT. For the salik, takwa is a person who can not escape from the act of purifying himself, the one who always tries to immerse himself in all the things that are commanded (ridha) of Allah and to abstain from all the acts of the wrath of Allah (Al-Jailani, 2017: 78). Thus the teaching brought by Emha Ainun Nadjib or Cak Nun in Ma'iyahan does not deviate from the Islamic corridor and the concept of scholarship in Sufism. The goal of Sufism is the heart and soul because if it is good, it will be all human body, and vice versa if it is bad, it is bad behavior. Because of the behavioral glory (akhlaq) is driven by a clean heart or soul (Gratitude, 2014: 240).

Forum Ma'iyahan Ema Ainun Nadjib also often even in every aspect inserted inscribed Islam through Sufi approach, when jama'ah ma'iyahan negate himself with the existence of God Almighty God as the concept of tajalli in Sufism. In the book of al-Luma' by Abu Nasr as-Sarraj, at-Tajalli is the control of the inner lights towards al-Haq in the hearts of those who want to face Him. An-Nuri rahimahullah said: Tajalli (appearance) Himself to beings is through creatures, as He closes Himself from beings with beings (As-Sarraj, 2002: 717-718). With Tajalli then all beauty will be good and beautiful, and itsar (close) Himself then beauty will be ugly. This, as Allah says in the surah of al-A'raf verse 143:

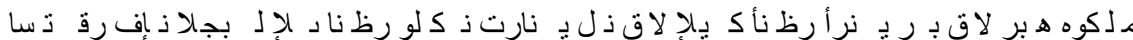

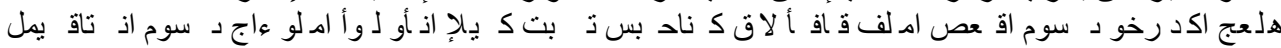

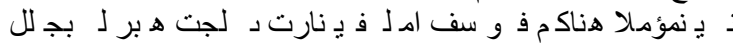

It means: "And when Moses came to Our appointed tryst and his Lord had spoken unto him, he said: My Lord! Show me (Thy Self), that I may gaze upon Thee. He said: Thou wilt not see Me, but gaze upon the mountain! If it stand still in its place, then thou wilt see Me. And when his Lord revealed (His) glory to the mountain He sent it crashing down. And Moses fell down senseless. And when he woke he said: Glory unto Thee! I turn unto Thee repentant, and I am the first of (true) believers." (QS. Al-A'raf:143)

Ibn Kathir declares in his book when Allah tajalli, then all creatures will feel death because of the greatness and the magnitude of Allah SWT. The interpretation of this verse has been put forth in Surah Al-An'am verse 130. As stated in the earlier books, Allah (SWT) said to Moses, 
"O Moses, there is no living creature that sees me to be dead, and There is no dead thing but he must be destroyed " (Alu Shaykh, 2008: 449-451).

\section{CONCLUSION}

Based on this brief explanation of this research, the researcher finds some things that can be drawn into a knowledge and conclusion from the object under study, that the study of the value of Sufism and science in ma'iyah circle is very wide and rich about the understanding of deconstruction.

Sociologically, Ma'iyahan is a form of religious social activity in society. Muhammad Ainun Nadjib or Cak Nun has a position as a public figure and religious elite who have bergaining position amid the growing dynamics of society. Similarly, from the economic point of view automatically makes ma'iyahan a new job for the people around the community even from outside the region by selling around ma'iyahan location with a variety of merchandise. In the aspect of education it is clear that ma'iyahan is a source of new knowledge that was not yet understood with the straightforward language of the speakers, but in ma'iyahan all will be exposed logically. And in terms of Sufism, ma'iyahan is a scientific container to understand tasawuf a fairly complicated in the community become closer and better understand both common sense and academics.

Ma'iyah is not a tarekat or modern tarekat form as in the practice of tasawuf, but ma'iyahan is a forum with the concept of Sufism.

Differences tarekat with ma'iyah can be seen from aspects of his community. Tariqah obliges its followers to bai'at (legalized) to the murshid (his supervisor) after following a routine directed by the murshid directly. However, unlike ma'iyah, in ma'iyah not know teacher or student, they are given freedom to think and look for each way according to that in herself and God. Ma'iyah does not prohibit and neither oblige nor enjoin Muslims or nonMuslims to join. For in ma'iyah only instill values to "God" and humanity. Whatever his religion, what tribe, as long as it does not do damage on earth.

It can also be said that the ma'iyah Forum initiated by Emha Ainun Nadjib has a very large contribution to the pattern of Islamic understanding in Indonesia, Because the method used in this ma'iyah forum is to elaborate between the state of the times, polemic, and the pattern of understanding of society in certain areas. Ma'iyah also provides a new style in the understanding of society against Sufism.

So, ma'iyah forum is not just an initiative, but because of a necessity of the times. As information gets blurry and its validity, then emerging epistemic communities, is a community that digs deeper through discussion forums on the polemics that occur in society than with general discussion.

\section{ACKNOWLEDGEMENT}

This research based on grant scheme of PITTA (Publikasi International Terindeks untuk Tugas Akhir) or also known as Indexed International Publications for Final Projects toward Universitas Indonesia students. Thank you to Dr. Muhammad Luthfi as my advisor.

\section{REFERENCES}


[1]. Abu Nasr As-Sarraj, Al-Luma': Rujukan Lengkap Ilmu Tasawuf, diterjemakan oleh Wasmukan dan Samson Rahman dari judul asli: Al-Luma': Lajnah Nasyr at- Turats ashShufi, (Surabaya: Risalah Gusti, 2002)

[2]. Al-Ghazali, Ihya' Ulumuddin, diterjemahkan oleh Yunasril ali, Pengantar Ilmu Tasawuf, (Jakarta: Pedoman Ilmu Jaya, 1987)

[3]. Al-Ghazali, Ihya' Ulumuddin, diterjemahkan oleh Ismail Yakub, Ihya' Al-Ghazali, (Jakarta: C.V. Faizan, 1989)

[4]. Syekh Abdul Qadir Al Jailani, Terjemah Sirr Al- Asrar, diterjemakan oleh Abdul Majid Hj. Khatib dari judul asli: Sirr al-Asrar Fi ma Yahtaj Ilayh al-Abrar, (Yogyakarta: Diva Press, 2017)

[5]. Ihsan Muhammad Dahlan, Siraj al-Thalibin: Syarh as-Syaikh Ikhsan Muhammad Dhlan al-Jampes Kediri 'ala Minhajul 'Abidin ila Jannatu al-'Alamin li al- Imam Hujjah alIslam Abu Hamid bin Muhammad al-Ghazali, Juz I, (Daar Kutub al-'Arabiyah)

[6]. Abdullah bin Muhammad bin 'Abdurrahman bin Ishaq Alu Syaikh, Tafsir Ibnu Katsir, diterjemahkan dari judul asli: Lubabut Tafsir min ibni Katsir, (Jakarta: Pustaka Imam Syafi'i, 2008)

[7]. Syamsun Ni'am, Wasiat Tarekat Hadratus Syekh Hasyim Asy’ari, (Jogjakarta: Ar- Ruzz Media, 2011)

[8]. Emha Ainun Nadjib, Indonesia Bagian dari Desa Saya, (Jakarta: Kompas Media Nusantara, 2016)

[9]. Emha Ainun Nadjib, Secangkir kopi Jon Pakir, (Bandung: PT. Mizan Pusataka, 2016)

[10]. Emha Ainun Nadjib, Jejak Tinju Pak Kiai, (Jakarta: Kompas Media Nusantara, 2016) Emha Ainun Nadjib, Kiai Bejo, Kiai Untung, Kiai Hoki, (Jakarta: Kompas Media Nusantara, 2016)

[11]. Robert Elliot, Ladislav Timulak, Descriptive and Interpretive approaches to Qualitative Research, (Oxford: Oxford University Press, 2013)

[12]. Vickie A. Lambert, Clinton E. Lambert, Qualitative Descriptive Research: An Acceptable Design,Journal of Nursing Research 2014

[13]. Amin Syukur, Tasawuf Sosial, (Yogyakarta: Pustaka Pelajar, 2004)

[14]. Amin Syukur, Tasawuf Kontekstual: Solusi Problem Manusia Modern, (Yogyakarta: Pustaka Pelajar, 2014)

[15]. Syamsun Ni’am, Wasiat Tarekat Hadratus Syekh Hasyim Asy’ari, (Jogjakarta: Ar- Ruzz Media, 2011)

[16]. Anwar Ali Yusuf, Studi Agama Islam Untuk Perguruan Tinggi, (Bandung: Pustaka Setia, 2003)

[17]. Quintan Wiktorowics, Islamic Activism: A Social Movement Theory Approach (Terjemah, Gerakan Sosial Islam: Teori Pendekan dan Studi Kasus), (Yogyakarta: Gading Publishing \& Yayasan Wakaf Paramadinah, 2012)

[18]. Achir Yani Hamid, Buku Ajar Aspek Spiritualitas dalam Keperawatan, (Jakarta: Widya Medika, 2000)

[19]. Majalah Sabana edisi 7 th II. Mei 2015

[20]. Prayogi R. Saputra, Spiritual Journey, Pemikiran dan Permenungan Emha Ainun Najdib (Jakarta:Kompas, 2012)

[21]. Emha Ainun Nadjib, Orang Maiyah, (Yogyakarta: Bentang Pustaka, 2015)

[22]. A. Busyairi Harist, Dakwah Kontekstual: Sebuah Refleksi Pemikiran Islam Kontemporer, (Yogyakarta: Pustaka Pelajar, 2012) 